\title{
ANALISIS STRATEGI PENGEMBANGAN USAHA BANK SAMPAH GARUDA WASTU LESTARI
}

\author{
Putri Anggreni
Program Sudi Manajemen, Fakultas Ekonomi, Universitas Mahendradatta Jl. Ken Arok No. 12, Peguyangan Denpasar Utara, Bali 80115
Email: gekcay@gmail.com

\begin{abstract}
Abstrak - Penelitian yang dilakukan di Bank Sampah Garuda Wastu Lestari yang berada di Kelurahan Peguyangan Kota Denpasar ini dilakukan dengan tujuan untuk menganalisis faktor-faktor lingkungan internal dan eksternal yang mempengaruhi pengembangan usaha bank sampah dan merumuskan alternatif strategi yang dapat diterapkan oleh Bank Sampah Garuda Wastu Lestari. Penentuan responden dilakukan secara sengaja dengan tujuan tertentu (purposive sampling). Responden dalam penelitian ini terdiri dari 4 (empat) orang responden yang berasal dari pihak manajemen perusahaan. Penyebaran kuesioner dilakukan untuk melakukan analisis lingkungan internal dan eksternal perusahaan. Penentuan alternatif strategi dilakukan menggunakan matriks SWOT dan penentuan prioritas strategi yang bisa diterapkan saat ini disesuaikan dengan posisi Bank Sampah Garuda Wastu Lestari dalam persaingan usaha. Dari diagram analisis SWOT terlihat bahwa perusahaan berada pada sel 1, yaitu pada sel Strategi Agresif. Sementara itu melalui hasil penyusunan matrik SWOT terdapat sebelas alternatif strategi yang bisa diterapkan oleh Bank Sampah Garuda Wastu Lestari. Prioritas pemilihan strategi yang bisa dilakukan dengan melihat posisi perusahaan dalam persaingan usaha saat ini adalah dengan Strategi S-O (Strenght-Opportunity), memanfaatkan kekuatan yang dimiliki untuk merebut peluang yang ada. Dengan demikian prioritas usaha yang tepat dilakukan adalah: 1) mempertahankan dan meningkatkan kualitas pelayanan yang dihasilkan; 2) mempertahankan dan meningkatkan hubungan baik dengan pekerja, nasabah; dan lembaga atau instansi terkait; 3) mempertahankan dan meningkatkan kegiatan promosi dan sosialisasi; serta 4) meningkatkan kerjasama dan jaringan bank sampah.
\end{abstract}

Kata kunci: manajemen strategis, strategi bisnis, bank sampah, analisis SWOT.

Abstract - Research conducted at Waste Bank Garuda Wastu Lestari is located in the Peguyangan Village, Denpasar was done in order to analyze the environmental factors that affect the internal and external business development of waste bank and formulate alternative strategies that can be applied by Waste Bank Garuda Wastu 
Lestari. Determination of respondent committed intentionally with a specific purpose (pusposive sampling). Respondents in this study consisted of four respondents from the management company. Questionnaires conducted to analyze the internal and external environment. Determination of strategic alternatives conducted using SWOT Matrix and prioritization strategy that can be applied at this time adapted to the position of Waste Bank Garuda Wastu Lestari in the competition. SWOT analysis of the diagram looks that the company is in cell 1, in the cell Aggressive Strategy. While the outcome of the preparation through the SWOT Matrix are eleven alternative strategies that can be applied by Waste Bank Garuda Wastu Lestari. Priority strategy selection can be done by looking at the company's position in the current competition is with Strategy SO (StrengthOpportunity), utilizing the strength to seize the opportunities that exist. Thus the right business priorities do is: 1) to maintain and improve the quality of care produced;2) maintain and enhance good relations with employees, customers, and the agency or agencies; 3) maintain and improve the promotion and dissemination activities; and 4) improve cooperation and networking of waste bank.

Key words: strategic management, business strategy, waste bank, SWOT analysis.

\section{PENDAHULUAN}

Indonesia merupakan salah satu negara yang memiliki penduduk sangat besar dan memiliki kecenderungan meningkat dari waktu ke waktu. Berdasarkan data Badan Pusat Statistik, selama 30 tahun terakhir, jumlah penduduk Indonesia meningkat hampir dua kali lipat, yaitu 147,49 juta jiwa pada tahun 1980, menjadi 179,37 juta jiwa pada tahun 1990, dan pada tahun 2000 bertambah mencapai 206,26 juta jiwa. Angka tersebut terus mengalami peningkatan dan mencapai 237,64 juta jiwa pada tahun 2010.

Jumlah penduduk yang terus meningkat akan mengakibatkan kemampuan sumber daya alam dapat pulih (misalnya air dan udara) untuk menyerap limbah yang diakibatkan oleh aktivitas manusia menjadi menurun (Faizah, 2008). Kenaikan jumlah penduduk tersebut juga akan meningkatkan volume sampah yang dihasilkan, terutama di kota-kota besar seperti Jakarta, Bandung, Surabaya, dan Yogyakarta.

Pulau Bali yang memiliki luas wilayah 5.632,8 kilometer persegi dengan daya dukung idealnya hanya 1,5 juta jiwa, kenyataannya kini berpenduduk 4,1 juta jiwa. Hasil penghitungan Badan Lingkungan Hidup (BLH) Provinsi Bali, produksi sampah di Bali mencapai 10.180 meter kubik per hari. Dari 10.180 meter kubik per hari produksi sampah di Bali yang tertangani hanya 60 persen. Sekitar 60 persen dari jumlah sampah yang tertangani tersebut belum disertai dengan proses 3R. Jadi ini baru begitu saja ditaruh, tidak ada pemisahan dan lain sebagainya. Akibat dari sampah yang besar ini 
satu lahan (tanah) akan mengalami degradasi.

Berdasarkan data sampah padat yang ada, sampah di Bali terdiri atas 70 persen sampah organik dan 30 persen anorganik (plastik, kertas, botol, besi, dll). Jika kita menggunakan perhitungan kapasitas sampah sebesar 10.000 ton per hari, maka komposisinya: 7.000 ton sampah organik dan 3.000 ton sampah anorganik. Dari dua produk standar di atas tersebut, dapat dihasilkan pendapatan sebesar Rp 11 milyar setiap hari, atau Rp 330 milyar setiap bulan, atau Rp 4,015 triliyun setiap tahun.

Sebagai ibukota Provinsi Bali, Kota Denpasar secara administrasi terdiri dari 4 kecamatan, 43 desa/kelurahan, dengan 209 dusun/banjar dinas. Semuanya memiliki fasilitas yang dibutuhkan masyarakat hal ini menjadi daya tarik kuat seluruh lapisan masyarakat dari berbagai daerah untuk datang dan tinggal, sehingga jumlah penduduk Kota Denpasar meningkat tajam menjadi 629.588 jiwa pada tahun 2011. Jumlah lahan kota yang terbatas tidak menghalangi arus urbanisasi dengan tujuan tinggal, menyebabkan makin kompleksnya permasalahan yang timbul di kota ini. Diantaranya adalah masalah sampah dan air bersih. Hingga saat ini belum ada yang mampu menyelesaikan secara tuntas permasalahan sampah.
Sebagai sebuah kota, Denpasar mengalami eksploitasi besar-besaran terhadap lingkungannya, permasalahan sampah, alih fungsi lahan hijau menjadi pemukiman seolah tidak terbendung. Bahkan menurut penelitian sejak tahun 1995 Kementrian Lingkungan Hidup memprediksi Bali akan mengalami defisit air sebanyak 1 miliar meter kubik per tahun dan akan terus meningkat hingga mencapai sekitar 27,6 miliar meter kubik pada tahun 2015. Pada saat tersebut juga diprediksi Bali akan mengalami kekurangan air bersih mencapai 1.500 liter per detik. Parahnya lagi intrusi air laut di bagian selatan Pulau Bali tepatnya di bagian selatan Kota Denpasar telah mencapai 5 kilometer dari batas pantai. Hal ini berarti kelangsungan hidup terancam jika tidak segera dilakukan aktivitas nyata sebagai wujud penyelamatan lingkungan di Bali khususnya di wilayah Kota Denpasar.

Sementara manajemen pengelolaan sampah belum ada perubahan signifikan dilakukan oleh aparat pemerintah. Ironisnya, pengelolaan sampah di Tempat Pembuangan Akhir (TPA) Suwung amburadul. Belum lagi TPA itu menerima kiriman sampah dari Badung. Kroditnya penanganan sampah dirasakan warga Denpasar akhir-akhir ini. Tumpukan sampah tersebar di beberapa Tempat 
Pembuangan Sementara (TPS) sampai meluber ke badan jalan. Kisruh amburadulnya kondisi di TPA Suwung juga disebabkan ada beberapa instansi yang mengadakan kegiatan di areal tersebut, seperti keberadaan PT Navigat Organic Energy Indonesia (NOEI).

Pada tahun 2011, Kota Denpasar menghasilkan lebih dari 1,15 juta meter kubik sampah, tetapi hanya 698.949 meter kubik dikumpulkan oleh lembaga terkait. Lebih dari 400.000 meter kubik yang tersisa tidak terangkut. Pada tahuntahun sebelumnya, sampah yang dikumpulkan di Denpasar adalah sekitar 724.586 meter kubik pada tahun 2010, 674.694 meter kubik pada tahun 2009, 698.217 meter kubik pada tahun 2008, dan 675.532 meter kubik pada tahun 2007.

Banyak cara telah ditempuh guna menangani sampah-sampah tersebut. Salah satunya dengan bank sampah. Bank sampah adalah tempat untuk menampung, memilah, dan mendistribusikan sampah ke fasilitas pengolahan sampah yang lain atau kepada pihak yang membutuhkan. Kunci utama ada pada pemilahan atau pemisahan sampah berdasarkan jenis dan kondisinya. Sama seperti bank konvensional, bank sampah juga mempunyai sistem manajerial dan masyarakat yang menjadi nasabahnya menabung dalam bentuk sampah.

Kian hari perkembangan gerakan bank sampah di Indonesia semakin pesat. Buktinya, dalam beberapa waktu belakangan ini sejumlah media cetak maupun online kerap memberitakan tentang pesatnya pertumbuhan gerakan bank sampah. Hal tersebut juga didukung dengan Dana Alokasi Khusus (DAK) dari Kementerian Lingkungan Hidup yang pemanfaatannya ada untuk bank sampah sehingga memacu kota-kota untuk membangun bank sampah. Di samping itu, bagi kota yang tidak membuat bank sampah maka nilai 3R (reuse, reduce, recycle) akan dikurangi atau bahkan tidak mendapatkan penghargaan Adipura.

Saat ini setidaknya telah ada

1.195 Bank Sampah di 58 kabupaten/kota dengan 106.000 tenaga kerja. Di mana keseluruhan bank sampah tersebut dapat menghasilkan Rp 15,7 miliar setiap bulan. Awalnya kehadiran bank sampah hanya untuk mengatasi permasalahan sampah saja, namun seiring makin besarnya kesadaran masyarakat akan pentingnya menjaga lingkungan membuat bank sampah saat ini telah menjadi tren. Hasilnya, bukan hanya efektif dalam menanggulangi sampah, bank sampah juga kini dapat memberikan dampak ekonomi bagi masyarakat. (Antara News, 1 Maret 2013).

Pengelolaan sampah saat ini diatur dengan Undang-Undang Nomor 18 tahun 2008 tentang Pengelolaan Sampah diperkuat Peraturan Pemerintah Nomor 81 Tahun 2012 tentang Pengelolaan Sampah Rumah Tangga dan Sampah Sejenis. Sementara itu aturan yang secara spesifik mengatur tentang Bank Sampah tertuang di dalam Peraturan Menteri Negara Lingkungan Hidup Nomor 13 Tahun 
2012 tentang Pedoman Pelaksanaan Reduce, Reuse, dan Recycle Melalui Bank Sampah.

Pendirian bank sampah di Indonesia pertama kali dilakukan masyarakat Dusun Badegan, Kabupaten Bantul, Yogyakarta dengan mendirikan Bank Sampah Gemah Ripah pada tanggal 5 Juni 2008. Bank sampah tersebut berada di bawah naungan Bengkel Kerja Kesehatan Lingkungan. Bank sampah didirikan karena melihat kebiasaan warga yang masih sering membakar sampah, menimbun sampah dan banyaknya warga Dusun Badegan yang terserang penyakit demam berdarah. Pengelola atau pengurus Bank Sampah Gemah Ripah ada yang memiliki pekerjaan tetap dan tidak tetap. Mereka bekerja secara sosial dan sukarela serta belum mendapat gaji karena berorientasi pada masyarakat belum profit.

Kemudian pada Januari 2010 di Jakarta didirikan Bank Sampah Karya Mandiri oleh Nanang Suwandi. Bank sampah ini terdapat di RT 05/09, Semper Barat, Koja, Jakarta Utara. Nasabahnya telah mencapai 500 orang. Sampah yang disetor ke Bank Sampah Karya Mandiri kemudian dinilai dengan Rupiah dan dicatat di buku tabungan. Selain tabungan, Bank Sampah Karya Mandiri juga memberikan pinjaman dan mendaur ulang sampah yang berhasil dihimpunnya. Pinjaman yang diberikan tanpa bunga, nasabah membayar pinjaman dengan menyetor sampah ke bank sampah.

Bank Sampah Bina Mandiri yang terdapat di RT 6/9 Bratang Lapangan Ngagelrejo, Bratang Surabaya, Jawa Timur. Didirikan oleh Anindhita Normaria, mahasiswa Institut Teknologi Surabaya pada tanggal 11 Oktober 2010. Bank sampah ini meniru Bank Sampah Gemah Ripah, bedanya nasabah dapat mengambil tabungan sewaktu-waktu. Nasabah Bank Sampah Bina Mandiri berjumlah 190 orang.

Di tahun 2011 berdiri Bank

Sampah Malang (BSM) Kota Malang. BSM diresmikan oleh Menteri Negara Lingkungan Hidup Bapak Prof. DR. Balthasar Kambuaya, MBA pada tanggal 15 November 2011. Tabungan yang ada di BSM meliputi : Tabungan Reguler, Tabungan Lebaran, Tabungan Sekolah, Tabungan Sembako, Tabungan Lingkungan, serta Tabungan Sosial. Motto BSM : "Pinjam Uang Nyicil Sampah" "Beli Sembako Bayar Sampah" Jumlah nasabah BSM sampai dengan akhir 2012 sudah mencapai 19.020 nasabah terdiri dari Unit Masyarakat 181 Kelompok, Unit Sekolah 161 Sekolah, Instansi 18, Individu 240 orang. Jumlah nasabah BSM dengan pengambilan rata-rata per hari 15 lokasi kelompok dengan 3 armada mobil pick up dan kapasitas rata-rata sampah yang diambil \pm 1 ton. 
Sementara itu di kota Denpasar sendiri sebelum berdirinya Bank Sampah Garuda Wastu Lestari, telah berdiri beberapa bank sampah diantaranya Bank Sampah Cahaya Partha Jaya, Bank Sampah Sedhana Arsa, serta Bank Sampah Kampung Petiles Kelurahan Dauh Puri. Masingmasing bank sampah tersebut mempunyai keunikan tersendiri dalam hal pengelolaan sampah yang berhasil dihimpun dari masyarakat yang menabung sampah.

Bank Sampah Cahaya Partha Jaya beralamat di Jalan Noja Sari No. 12X Kesiman Denpasar Timur. Pendirinya adalah Bapak Made Bagiada yang telah belasan tahun bersama keluarganya menekuni jual beli barang lapak. Tahun 2011 mulai dikembangkan usahanya membuka Bank Sampah dengan 237 nasabah dari Denpasar, Bangli, Klungkung, Tabanan dan Badung. Mulai dari hotel, perkantoran, toko, bengkel, sekolah dan individu. Bersama 10 stafnya, mereka mampu melayani dengan penjemputan ke lokasi para nasabah jika dibutuhkan. Keuntungan menjadi nasabah di bank ini, selain menyetor sampah pulang bawa uang, ternyata juga ada simpan pinjam. Pinjaman tidak dikenakan bunga dan pengembalian pinjaman tetap berupa sampah bukan uang. Tentu saja semua ada ketentuan yang mesti diikuti.

Bank Sampah Sedhana Arsa beralamat Jalan Tukad Balian, Renon.
Berawal dari kepedulian terhadap sampah di Denpasar juga membuat Bapak Wayan Suarta berani mengambil profesi sebagai pengelola sampah di Desa Renon. Sebenarnya di Renon sudah ada satu depo yang melayani pengambilan sampah dari masyarakat tetapi belum bisa melayani semua warga. Maka sejak tahun 2008 mulai berdiri Yayasan Mega Lestari dalam usaha jasa pelayanan pengangkutan sampah. Sampai saat ini pelanggannya sudah mencapai 4.500 mulai dari rumah tangga, restoran, hotel dan kantor. Lokasi pelanggan Denpasar, Badung dan Gianyar. Dalam perkembangannya membuka Bank Sampah Sedhana Arsa. Pelayanan bisa diantar sendiri oleh pelanggan, atau permintaan penjemputan ke lokasi sampah namun biasanya diperhitungkan jumlah sampahnya.

Bank Sampah Kampung Petiles dikelola oleh I Gede Arya Wardana, beralamat di Jalan Pulau Buru No. 24D Banjar Catur Panca, Kelurahan Dauh Puri Denpasar Barat. Adapun Kegiatan dalam area bank sampah ini terdapat pembuatan/pengolahan sampah menjadi gas metana untuk kompor, pengolahan sampah menjadi kompos (composting) serta pembuatan lobang resapan biopori untuk menghilangkan genangan air/banjir serta konservasi air tanah. Bank sampah Kampung Petiles dibangun untuk belajar dan berinvestasi dalam mengelola sampah 
berbasis masyarakat menuju Kelurahan Dauh Puri yang bersih dan hijau berwawasan budaya.

Walaupun bukan merupakan bank sampah yang pertama kali didirikan di Kota Denpasar, bukan berarti peran Bank Sampah Garuda Wastu Lestari dapat diabaikan. Justru bank sampah ini yang menunjukkan perkembangan yang pesat dalam menjaring partisipasi masyarakat Kota Denpasar. Dalam keberadaannya yang baru berumur 1,5 tahun, usaha ini telah mampu mengumpulkan anggota (nasabah penabung sampah) hingga lebih dari 300 nasabah individu dan komunal.

Selain itu yang lebih menarik lagi adalah peran bank sampah yang berada di bawah naungan Lembaga Bali Wastu Lestari ini sebagai pendamping dan pengepul dari beberapa bank sampah lainnya di Kota Denpasar yang tergabung dalam Sekaa Bank Sampah Kota Denpasar. Hingga kini lebih dari tiga puluh unit bank sampah berhasil dibina dan didampingi, belasan banjar dan puluhan sekolah baik SD, SMP, dan SMA bergabung dalam pengelolaan sampah bersama Bank Sampah Garuda Wastu Lestari.

Dalam hal penyelenggaran produk (jasa dan barang) terkait pengelolaan sampah masih mempunyai potensi besar untuk dikembangkan. Apalagi mengingat timbulan sampah, khusunya di Kota Denpasar, mengalami peningkatan yang signifikan dari tahun ke tahun seiring pertumbuhan penduduk yang tinggi di Ibu Kota Provinsi Bali ini melampaui pertumbuhan penduduk rata-rata seluruh Bali.

Melihat perkembangan Bank Sampah Garuda Wastu Lestari yang demikian perlu dilakukan suatu penelitian guna menganalisis strategi pengembangan usaha yang dijalankan oleh Bank Sampah Garuda Wastu Lestari. Berdasarkan uraian tersebut peneliti tertarik untuk mengadakan penelitian dengan mengambil judul "Analisis Pengembangan Usaha Bank Sampah Garuda Wastu Lestari”.

Adapun rumusan masalah dalam penelitian ini sebagai berikut: 1) Faktor internal dan eksternal apa saja yang berpengaruh terhadap usaha Bank Sampah Garuda Wastu Lestari? dan 2) Bagaimana alternatif dan prioritas strategi yang tepat untuk diterapkan pada Bank Sampah Garuda Wastu Lestari sesuai dengan kondisi lingkungan usahanya?

Tujuan penelitian ini antara lain: 1) Menganalisis faktor-faktor lingkungan internal dan eksternal yang mempengaruhi pengembangan usaha Bank Sampah Garuda Wastu Lestari; 2) Merumuskan alternatif strategi yang dapat diterapkan oleh pihak Bank Sampah Garuda Wastu Lestari.

KAJIAN PUSTAKA 


\section{Konsep Manajemen Strategis}

Manajemen strategis dapat didefinisikan sebagai seni dan pengetahuan dalam merumuskan, mengimplementasikan, serta mengevaluasi keputusan-keputusan lintas fungsional yang memungkinkan sebuah organisasi dapat mencapai tujuannya. Manajemen strategis berfokus pada mengintegrasikan manajemen, pemasaran, keuangan/akuntansi, produksi/operasi, penelitian dan pengembangan, serta sistem informasi komputer untuk mencapai keberhasilan organisasi. (David, 2011:5)

Tujuan manajemen strategis adalah untuk mengeksploitasi serta menciptakan berbagai peluang baru yang berbeda untuk masa mendatang, perencanaan jangka panjang, sebaliknya, mencoba untuk mengoptimalkan kecenderungan dewasa ini untuk masa mendatang. Proses manajemen strategis menurut David (2011:6), terdiri atas tiga tahap: perumusan strategi, penerapan strategi, dan penilaian strategi, dengan alur proses manajemen strategis seperti terlihat pada Gambar 1.

Perumusan strategi mencakup pengembangan visi dan misi, identifikasi peluang dan ancaman eksternal suatu organisasi, kesadaran akan kekuatan dan kelemahan internal, penetapan tujuan jangka panjang, pencarian strategi-strategi alternatif, dan pemilihan stretegi tertentu untuk mencapai tujuan. Penerapan strategi mengharuskan perusahaan untuk menetapkan tujuan tahunan, membuat kebijakan, memotivasi karyawan, dan mengalokasikan sumber daya, sehingga strategi-strategi yang telah dirumuskan dapat dijalankan.

$$
\text { Manajemen strategis }
$$

memungkinkan sebuah organisasi untuk lebih produktif alih-alih reaktif dalam membangun masa depannya, memungkinkan suatu organisasi untuk mengarahkan dan memengaruhi (alih-alih sekadar memberikan respon) pada berbagai aktivitas dan dengan demikian mengontrol takdirnya sendiri. Komunikasi adalah kunci sukses bagi manajemen strategis yang berhasil. Melalui keterlibatan di dalam prosesnya, manajer dan karyawan berkomitmen untuk mendukung organisasi. Dialog dan partisipasi merupakan bahan penyusun yang penting (David, 2011:23).

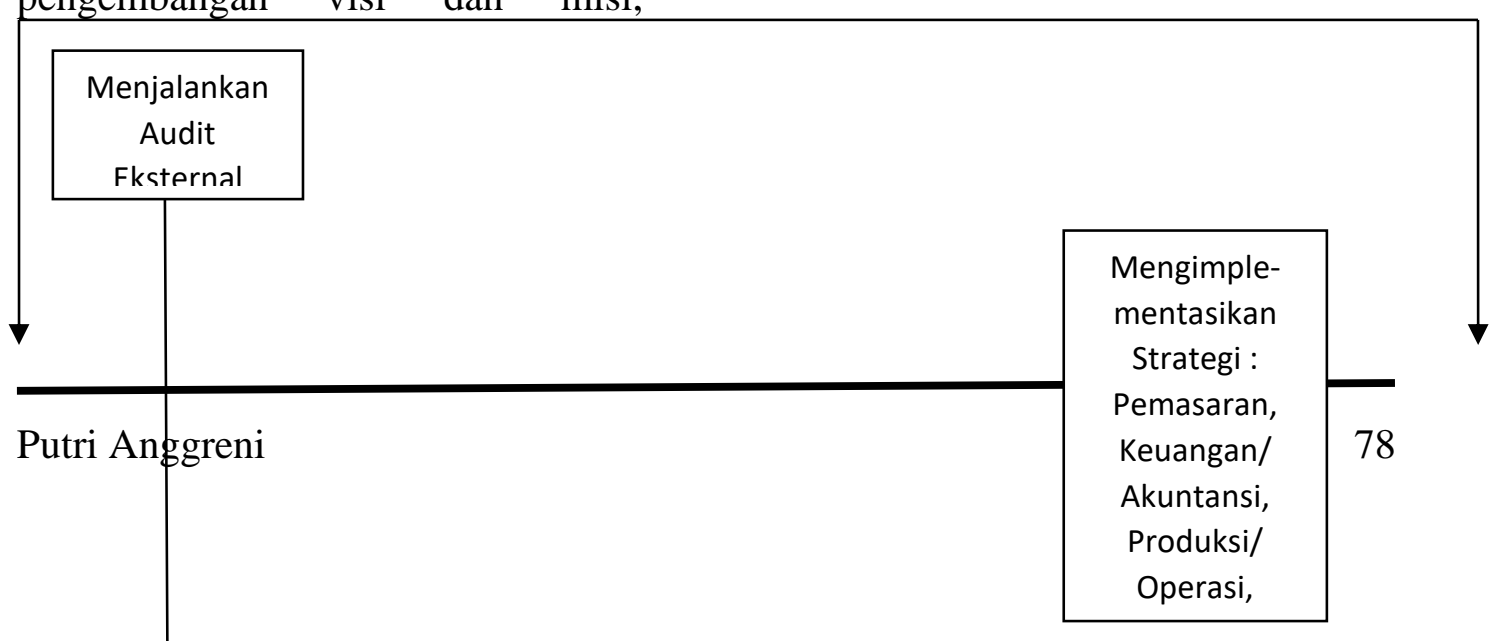




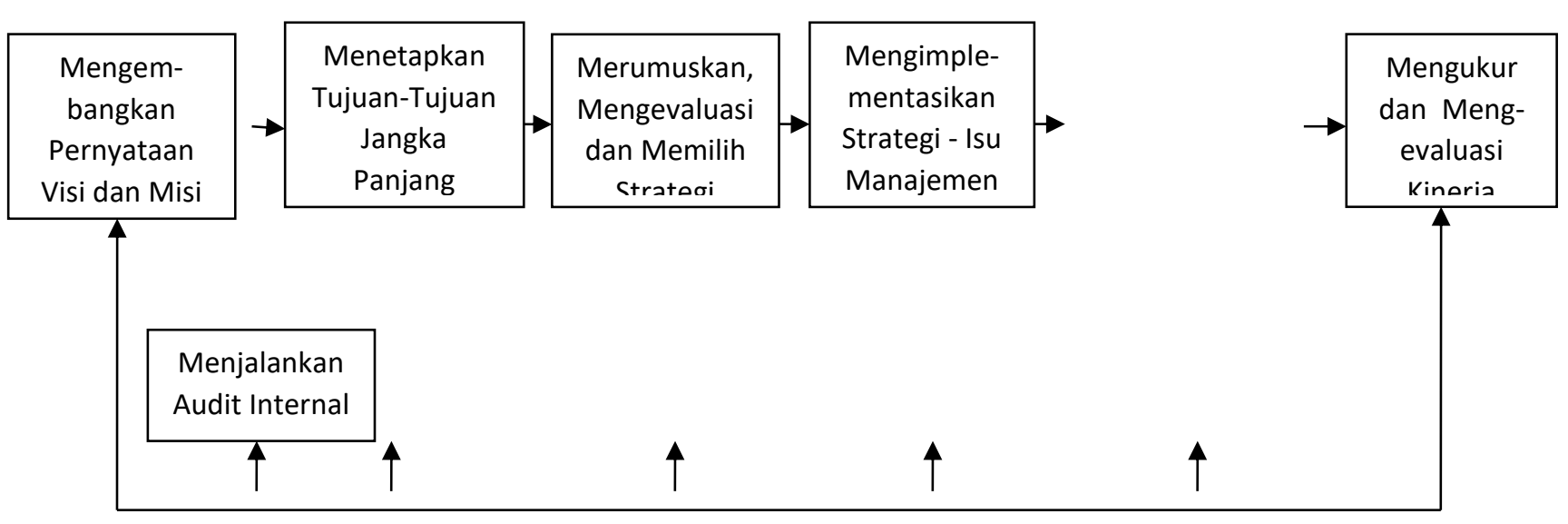

Sumber: Fred R. David (2011:21)

\section{Gambar 1. Model Komprehensif Manajemen Strategis}

\section{Strategi Bisnis}

Strategi adalah tujuan jangka panjang dari suatu perusahaan, serta pendayagunaan dan alokasi semua sumber daya yang penting untuk mencapai tujuan tersebut. Ada beberapa konsep yang sangat menentukan suksesnya strategi yang disusun antara lain: 1) Distinctive competence menjelaskan kemampuan spesifik yaitu suatu perusahaan yang memiliki kekuatan yang tidak mudah ditiru oleh perusahaan pesaing yang meliputi keahlian tenaga kerja dan kemampuan sumber daya; 2) Competetive adventage menjelaskan keunggulan bersaing oleh pilihan strategi dilakukan untuk merebut peluang pasar meliputi cost leadership, diferensiasi dan fokus.

Suatu perusahaan bisa dikatakan berhasil apabila dapat mengembangkan dan menjalankan strategi untuk mengatasi berbagai ancaman baik internal maupun eksternal dan meraih peluang yang ada. Proses analisis, perumusan dan evaluasi strategi-strategi itu disebut perencanaan strategis. Tujuan utama perencanaan strategi adalah agar perusahaan dapat melihat secara objektif kondisi-kondisi internal dan eksternal perusahaan, sehingga perusahaan dapat mengantisipasi perubahan lingkungan eksternal. Perencanaan strategi penting untuk memperoleh keunggulan bersaing dan memiliki produk yang sesuai dengan keinginan konsumen dengan dukungan yang optimal dari sumber daya yang ada.

Menurut Porter (1997:71) perencanaan strategis adalah proses manajerial untuk mengembangkan dan menjaga agar tujuan, keahlian dan sumber daya organisasi sesuai dengan peluang pasar yang terus berubah. Tujuan perencanaan 
strategis adalah untuk membentuk dan menyempurnakan usaha serta produk perusahaan sehingga memenuhi target laba pertumbuhan. Perencanaan strategis memerlukan tiga kegiatan kunci, yaitu: 1) Perusahaan mengelola usahanya sebagai portofolio investasi. Setiap usaha memiliki potensial laba yang berbeda, dan sumber daya yang dimiliki perusahaan harus dialokasikan dengan tepat; 2) Perusahaan mengevaluasi setiap unit usaha secara tepat dengan mempertimbangkan tingkat pertumbuhan pasar dan posisi serta kesesuaian perusahaan dalam pasar tersebut; 3) Perusahaan harus mengembangkan suatu rencana permainan untuk mencapai tujuan jangka panjang dan menentukan strategi apa yang paling sesuai dari sudut pandang posisi industri dan tujuan, peluang, keahlian, dan sumber dayanya.

\section{Bank Sampah}

Menurut Peraturan Menteri Negara Lingkungan Hidup Republik Indonesia Nomor 13 Tahun 2012, bank sampah adalah tempat pemilahan dan pengumpulan sampah yang dapat didaur ulang dan/atau diguna ulang untuk dijadikan memiliki nilai ekonomi. Di dalam bank sampah dilaksanakan kegiatan reduce, reuse, dan recycle (3R). Kegiatan 3R tersebut dilaksanakan terhadap sampah rumah tangga dan sampah sejenis sampah rumah tangga. Ruang lingkup Peraturan Menteri ini meliputi: 1) Persyaratan bank sampah; 2) Mekanisme kerja bank sampah; 3) Pelaksanaan bank sampah; dan 4) Pelaksana bank sampah.

\section{Analisis SWOT}

Dalam upaya melakukan identifikasi lingkungan strategis baik internal maupun eksternal, analisis SWOT merupakan metode yang paling umum digunakan. Hal ini mengacu pada pendapat Pearce dan Robinson (2008:200) yang mengatakan bahwa analisis SWOT merupakan teknik historis yang terkenal dimana para manajer menciptakan gambaran umum secara cepat mengenai situasi strategis perusahaan. Analisis ini didasarkan pada asumsi bahwa strategi yang efektif diturunkan dari "kesesuaian" yang baik antara internal perusahaan (kekuatan dan kelemahan) dengan situasi eksternalnya (peluang dan ancaman). Kesesuaian yang baik akan memaksimalkan kekuatan dan peluang perusahaan serta meminimalkan kelemahan dan ancaman.

Dalam membuat keputusan perusahaan perlu pertimbangan faktor internal yang mencakup kekuatan dan kelemahan maupun faktor eksternal yang mencakup peluang dan ancaman. Dalam hal ini analisis SWOT dipakai jika para penentu strategi perusahaan mampu melakukan pemaksimalan peranan faktor kekuatan dan memanfaatkan peluang sekaligus berperan sebagai alat untuk meminimalisi kelemahan 
yang terdapat dalam tubuh organisasi dan menekan ancaman yang timbul dan harus dihadapi dengan tepat.

Sel 1: Ini merupakan situasi yang sangat menguntungkan perusahaan tersebut memiliki peluang dan kekuatan sehingga dapat memanfaatkan peluang yang ada, strategi yang harus diterapkan dalam kondisi ini adalah mendukung kebijakan pertumbuhan yang agresif.

Sel 2: Meskipun menghadapi berbagai ancaman, perusahaan ini masih memiliki kekuatan dari segi internal. Strategi yang harus diterapkan adalah menggunakan kekuatan memanfaatkan peluang jangka panjang dengan cara strategi diversifikasi (produk atau pasar).

Sel 3 : Perusahaan menghadapi peluang pasar yang sangat besar, tetapi di lain pihak, ia menghadapi beberapa kendala atau kelemahan internal. Fokus strategi perusahaan ini adalah meminimalkan masalah-masalah internal perusahaan sehingga dapat merebut peluang pasar yang lebih baik

Sel 4: Ini merupakan situasi yang sangat tidak menguntungkan. Perusahaan tersebut menghadapi berbagai ancaman dan kelemahan internal.

Analisis SWOT digunakan sebagai penentu kebijakan strategi perusahaan atau organisasi dalam memaksimalkan faktor kekuatan dan memanfaatkan peluang yang ada sekaligus berperan memperkecil kelemahan yang ada dalam perusahaan serta menekan berbagai ancaman yang akan timbul.

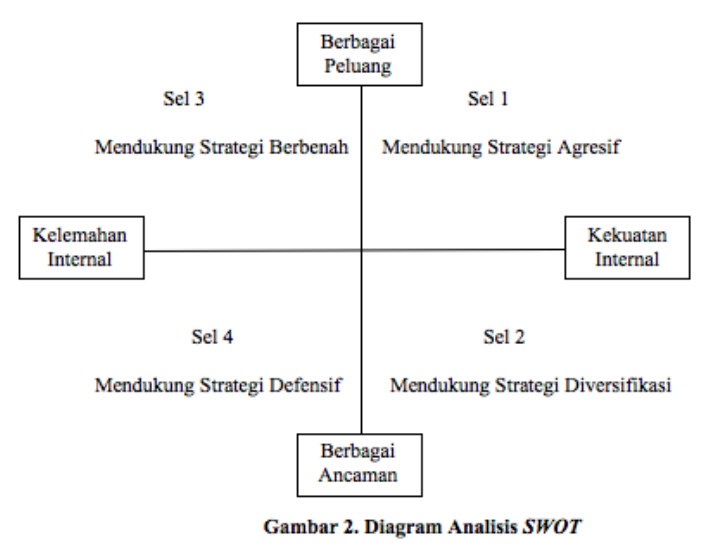

METODE PENELITIAN

Metode Penentuan Responden

Penentuan responden

dilakukan secara sengaja dengan tujuan tertentu (purposive sampling). Menurut David (2006:206), dalam analisis ini untuk menentukan responden, tidak ada jumlah minimal yang diperlukan, sepanjang 
responden yang dipilih merupakan ahli di bidangnya. Responden adalah orang-orang yang mengenal betul dinamika dan keadaan bisnis yang dijalani. Responden dalam penelitian ini terdiri dari empat orang responden yang berasal dari pihak internal Bank Sampah Garuda Wastu Lestari, yaitu manajer, bendahara, sekretaris, serta seorang dari bagian divisi.

\section{Data dan Instrumentasi}

Data yang digunakan dalam penelitian terdiri dari data primer dan data sekunder. Data primer diperoleh secara langsung dari perusahaan (Garuda Wastu Lestari) baik dari hasil wawancara dan dari hasil observasi langsung yaitu dengan melihat dan mengamati situasi perusahaan, mengumpulkan dan mencatat data jumlah anggota, volume reduksi sampah, serta besar omset yang diperoleh oleh bank sampah. Data primer berupa faktorfaktor strategis internal dan eksternal diperoleh dengan cara wawancara menggunakan responden sebagai narasumber.

Narasumber
pengambilan informasi tentang
faktor-faktor internal dipilih dari
pimpinan perusahaan (manajer).
Tujuan dari pemilihan responden
tersebut adalah dengan anggapan
bahwa pimpinan perusahaan akan
lebih mengetahui faktor-faktor
internal dan eksternal apa saja yang

dapat mempengaruhi perusahaan yang dipimpinnya. Wawancara juga dilakukan dengan pesaing terdekat untuk membandingkan kondisi eksternal. Wawancara dengan pihak eksternal ini dilakukan terhadap beberapa orang diantaranya: manajer Bank Sampah Pertiwi, seorang pemilik lapakan sampah dekat lokasi bank sampah, serta seorang pemulung yang beroperasi di sekitar wilayah kerja bank sampah.

Data sekunder dapat diperoleh dari beberapa buku yang terkait dengan penelitian, studi pustaka, literatur dari instansi yang terkait seperti Badan Pusat Statistik (BPS), jurnal dan artikel. Data sekunder berupa pendukung penelitian melalui penelitian-penelitian sebelumnya dapat diperoleh dari skripsi sebelumnya, dan browsing internet guna mencari data yang mendukung penelitian.

\section{Teknik Pengumpulan Data}

Teknik yang digunakan dalam pengumpulan data adalah dengan metode pengamatan langsung, wawancara, studi pustaka, serta dokumentasi.

\section{Pengamatan Langsung} (Observasi), adalah pengumpulan data yang dilakukan dengan cara pengamatan dan pencatatan langsung secara sistematik terhadap obyeknya untuk mengetahui langsung kegiatankegiatan yang dilakukan atau 
masalah-masalah yang ditemukan dalam obyek penelitian. Bentuk observasi yang digunakan dalam penelitian ini adalah partisipasi moderat (moderate participation). Dalam observasi ini terdapat keseimbangan antara peneliti menjadi orang dalam dengan orang luar. Peneliti dalam mengumpulkan data ikut observasi partisipatif dalam beberapa kegiatan, tetapi tidak semua.

Wawancara (Interview), dilakukan dengan mengadakan wawancara langsung dengan pengurus, nasabah, serta pesaing usaha Bank Sampah Garuda Wastu Lestari. Wawancara merupakan sejumlah pertanyaan yang digunakan untuk memperoleh data dari responden baik dalam bentuk laporan pribadi, pendapat, ataupun opininya serta hal lain yang ingin diketahui berkaitan dengan penelitian. Dalam penelitian ini wawancara mendalam (depth interview) telah dilakukan sejak studi pendahuluan.

Kuesioner, pengumpulan data dengan menggunakan daftar pertanyaan yang diberikan kepada para responden yang berasal dari pihak manajemen Bank Sampah Garuda Wastu Lestari. Adapun tujuan dari penyebaran kuesioner adalah untuk mendapatkan data mengenai pembobotan serta penilaian faktor-faktor internal dan eksternal penentu kunci sukses pengembangan usaha Bank Sampah Garuda Wastu Lestari.

Studi Pustaka, yaitu pengumpulan data atau informasi dengan menggunakan buku-buku atau literatur-literatur yang berhubungan dengan penelitian dan bertujuan untuk menemukan teori, konsep, dan variabel lain yang dapat mendukung penelitian. Di dalam metode studi pustaka ini, peneliti mencari data melalui referensireferensi, jurnal dan artikel, serta browsing di internet.

Dokumentasi, yaitu teknik pengumpulan data dengan dokumen (catatan peristiwa yang sudah berlalu). Dokumen bisa berbentuk tulisan maupun gambar, seperti: laporan, catatan, serta berbagai foto yang berkaitan dengan obyek penelitian. Studi dokumen merupakan pelengkap dari observasi, wawancara, serta studi kepustakaan.

\section{Pendekatan Penelitian}

Sesuai dengan judul, rumusan masalah dan tujuan penelitian, maka penelitian ini menggunakan pendekatan penelitian kualitatif. Pengertian dari penelitian kualitatif adalah tradisi tertentu dalam ilmu pengetahuan sosial yang secara fundamental bergantung pada pengamatan pada manusia dalam kawasannya sendiri dan berhubungan dengan orang-orang tersebut, dalam bahasanya dan dalam peristilahannya.

Analisis kualitatif dilakukan untuk mengetahui gambaran tentang strategi pengembangan usaha, menganalisis faktor-faktor lingkungan internal dan eksternal yang mempengaruhi pengembangan usaha, serta merumuskan alternatif strategi yang dapat diterapkan. Menurut Nazir (2005:54), metode kualitatif adalah suatu metode dalam 
meneliti status kelompok manusia, suatu objek, suatu set kondisi, suatu sistem pemikiran ataupun suatu kelas peristiwa pada masa sekarang.

\section{Penelitian kualitatif} menggunakan metode kualitatif, metode ini digunakan karena beberapa pertimbangan. Pertama, menyesuaikan metode kualitatif lebih mudah apabila berhadapan dengan kenyataan ganda. Kedua, metode ini menyajikan secara langsung hakikat hubungan antara peneliti dan responden. Ketiga, metode ini lebih peka dan lebih dapat menyesuaikan diri dengan banyak penajaman pengaruh bersama dan terhadap polapola nilai yang dihadapi.

\section{Metode Pengolahan dan Analisis Data}

Data yang diperoleh dianalisis dengan menggunakan metode deskriptif. Tujuan metode deskriptif adalah untuk memberikan gambaran secara sistematis, aktual, dan akurat mengenai fakta-fakta, sifat-sifat, serta hubungan antara fenomena yang diteliti. Analisis dan pengolahan data dilakukan secara kualitatif melalui pendekatan konsep manajemen strategis. Analisis kualitatif digunakan untuk mengetahui lingkungan perusahaan terkait dengan kekuatan, kelemahan, peluang, dan ancaman yang dihadapi perusahaan yaitu menggunakan analisis SWOT dalam penentuan alternatif strategi.
Berdasarkan

analisis lingkungan internal dan eksternal perusahaan maka dapat diformulasikan alternatif strategi yang dapat dilaksanakan. Formulasi alternatif strategi dilakukan dengan menggunakan analisis SWOT yaitu menganalisis peluang, ancaman, kekuatan, dan kelemahan. Untuk menentukan faktor-faktor yang menjadi kekuatan, kelemahan, peluang, dan ancaman dilakukan wawancara interaktif dengan pihak perusahaan.

Pada proses awal wawancara peneliti berusaha mencari informasi keadaan internal diantaranya mengenai manajemen, pemasaran dan distribusi, keuangan dan akuntansi, produksi dan pelayanan jasa, penelitian dan pengembangan, sumber daya manusia, serta sistem informasi.

Setelah informasi tersebut terkumpul kemudian peneliti membuat daftar faktor kekuatan dan kelemahan perusahaan yang kemudian dikonfirmasikan kembali dengan pihak perusahaan dengan tujuan memastikan bahwa daftar kekuatan dan kelemahan yang dibuat tersebut sudah menggambarkan kondisi internal perusahaan. Kemudian peneliti juga melakukan wawancara untuk mendapatkan informasi tentang faktor-faktor eksternal yang mempengaruhi 
perusahaan berdasarkan lingkungan jauh dan lingkungan industri.

Pada tahapan ini peneliti memberikan panduan secara umum tentang faktor-faktor yang ada di dalam lingkungan jauh dan lingkungan industri. Kemudian pihak perusahaan memberikan penjelasan tentang pengaruh faktor-faktor tersebut terhadap perusahaan. Dari hasil penjelasan yang didapat peneliti membuat daftar peluang dan ancaman yang kemudian di konfirmasikan kembali dengan pihak perusahaan.

Peneliti juga melakukan wawancara dengan pihak pesaing terdekat untuk mendapatkan informasi apakah faktor yang menjadi peluang dan ancaman pada Bank Sampah Garuda Wastu Lestari juga berpengaruh terhadap usaha yang dijalankan pihak pesaing. Setelah mendapatkan data peluang, ancaman, kekuatan dan kelemahan, tahap yang dilakukan selanjutnya adalah melakukan analisis SWOT.
Analisis SWOT yang dilakukan dengan melibatkan empat orang responden dalam penelitian ini, langkah-langkahnya adalah sebagai berikut: 1) Identifikasi faktor-faktor internal dan eksternal lingkungan usaha bank sampah dilakukan dengan cara wawancara mendalam dengan pihak pimpinan Bank Sampah Garuda Wastu Lestari; 2) Hasil wawancara tersebut disajikan ulang dalam bentuk kuesioner yang akan dibagikan kepada pihak internal perusahaan yang dipilih menjadi responden; 3) Kuesioner tahap I diserahkan kepada responden untuk menentukan pembobotan faktor-faktor strategis penentu kunci sukses pengembangan Bank Sampah Garuda Wastu Lestari; 4) Kuesioner tahap II diisi para responden kemudian dinilai dengan Skala Likert.

Tabel 1. Kriteria Hasil Analisis

\begin{tabular}{|l|l|l|}
\hline Nilai & Rentang & Keterangan \\
\hline 4 & $3,25-4,00$ & Sangat Baik \\
\hline 3 & $2,50-3,24$ & Baik \\
\hline 2 & $1,75-2,49$ & Buruk \\
\hline 1 & $1,00-1,74$ & Sangat Buruk \\
\hline
\end{tabular}

Langkah selanjutnya penyusunan matriks SWOT. Matriks SWOT adalah alat untuk mencocokkan bagi para manajer dalam mengembangkan empat tipe strategi: SO (kekuatan-peluang), WO (kelemahan-peluang), ST (kekuatanancaman), WT (kelemahan-ancaman).
Mencocokkan faktor eksternal dan internal kunci merupakan bagian sulit terbesar untuk mengembangkan matriks SWOT dan memerlukan penilaian yang baik, dan tidak ada satu pun kecocokan terbaik (David, 2006:344). 
Matriks SWOT frontal dalam lingkungan eksternal. menggambarkan secara jelas bagaimana peluang dan ancaman dapat disesuaikan dengan kekuatan dan kelemahan. Strategi $S O$ atau strategi kekuatan-peluang menggunakan kekuatan internal perusahaan untuk memanfaatkan peluang eksternal. Strategi $W O$ atau strategi kelemahan-peluang bertujuan untuk memperbaiki kelemahan dengan memanfaatkan peluang eksternal.

Strategi ST atau strategi kekuatan-ancaman menggunakan kekuatan perusahaan untuk menghindari atau mengurangi dampak ancaman eksternal. Hal ini tidak berarti bahwa organisasi yang pasti selalu menghadapi ancaman

\begin{tabular}{|c|c|c|}
\hline $\begin{array}{l}\text { Faktor-faktor } \\
\text { Eksternal }\end{array}$ & $\frac{\text { Kekuatan }(\mathbf{S})}{\text { Daftar kekuatan }}$ & $\frac{\text { Kelemahan }(\mathbf{W})}{\text { Daftar kelemahan }}$ \\
\hline$\frac{\text { Peluang }(\mathbf{O})}{\text { Daftar peluang-peluang }}$ & $\begin{array}{l}\text { Strategi S-O } \\
\text { Membuat strategi } \\
\text { dengan } \\
\text { menggunakan } \\
\text { kekuatan untuk } \\
\text { memanfaatkan } \\
\text { peluang }\end{array}$ & $\begin{array}{l}\text { Strategi W-O } \\
\text { Membuat strategi yang } \\
\text { memanfaatkan peluang } \\
\text { untuk mengatasi } \\
\text { kelemahan }\end{array}$ \\
\hline $\begin{array}{l}\text { Ancaman }(\mathbf{T}) \\
\text { Daftar ancaman-ancaman } \\
\text { eksternal }\end{array}$ & $\begin{array}{l}\text { Strategi S-T } \\
\text { Membuat strategi } \\
\text { yang } \\
\text { menggunakan } \\
\text { kekuatan } \\
\text { untuk menghindari } \\
\text { ancaman-ancaman. }\end{array}$ & $\begin{array}{l}\text { Strategi W-T } \\
\text { Membuat strategi yang } \\
\text { meminimumkan } \\
\text { kelemahan dan } \\
\text { menghindari ancaman. }\end{array}$ \\
\hline
\end{tabular}

Gambar 3. Matriks SWOT 
Berdasarkan Gambar 3, diperoleh 8 (delapan) langkah dalam menyusun matriks SWOT, yaitu: 1) Menentukan faktor-faktor peluang eksternal organisasi atau perusahaan; 2) Menentukan faktor-faktor ancaman organisasi atau perusahaan; 3) Menentukan faktor-faktor kekuatan organisasi atau perusahaan; 4) Menentukan faktor-faktor kelemahan organisasi atau perusahaan; 5) Mencocokkan kekuatan internal dengan peluang eksternal untuk mendapatkan strategi $S$ - $O$. Catat hasil strategi $S$ - $O$ dalam sel yang ditentukan; 6) Mencocokkan kelemahan internal dengan peluang eksternal untuk mendapatkan strategi $W-O$. Catat hasil strategi $W-O$ dalam sel yang ditentukan; 7) Mencocokkan kekuatan internal dengan ancaman eksternal untuk mendapatkan strategi $S-T$. Catat hasil strategi $S-T$ dalam sel yang ditentukan; 8) Mencocokkan kelemahan internal dengan ancaman eksternal untuk mendapatkan strategi $W-T$. Catat hasil strategi $W-T$ dalam sel yang ditentukan.

Tahapan terakhir adalah penentuan alternatif strategi yang dilakukan dengan cara wawancara secara langsung dengan manajer perusahaan. Wawancara yang dilakukan bertujuan untuk mengetahui alternatif strategi yang bisa dijalankan oleh perusahaan dengan mengacu pada hasil analisis SWOT, kemudian menentukan alternatif strategi yang mungkin untuk terlebih dahulu dijalankan secara berurutan.

\section{PEMBAHASAN}

\section{Diagram Analisis SWOT}

Penilaian faktor strategis internal dan faktor strategis eksternal yang telah dilakukan dan mendapatkan hasil kemudian akan dimasukkan ke dalam diagram SWOT. Titik tengah diagram SWOT didapat dari rata-rata skala rating yaitu:

$$
\begin{aligned}
& \text { Titik } \frac{\text { Skala Penilaian }}{\text { Tengah }=} \\
&=\frac{4+3+2+1}{4} \\
& \text { Skala }
\end{aligned}
$$

Titik tengah diagram yaitu nilai tengah 2,50. Nilai awal garis horizontal adalah di sebelah kiri dan nilai awal dari garis vertikal adalah di sebelah bawah.

Hasil penilaian para responden menunjukan posisi Bank Sampah Garuda Wastu Lestari adalah posisi dengan variabel internal 3,25. Dan variabel eksternal 2,92. Letak posisi Bank Sampah Garuda Wastu Lestari dapat dilihat dalam diagram analisis SWOT seperti gambar 4.2 berikut: 


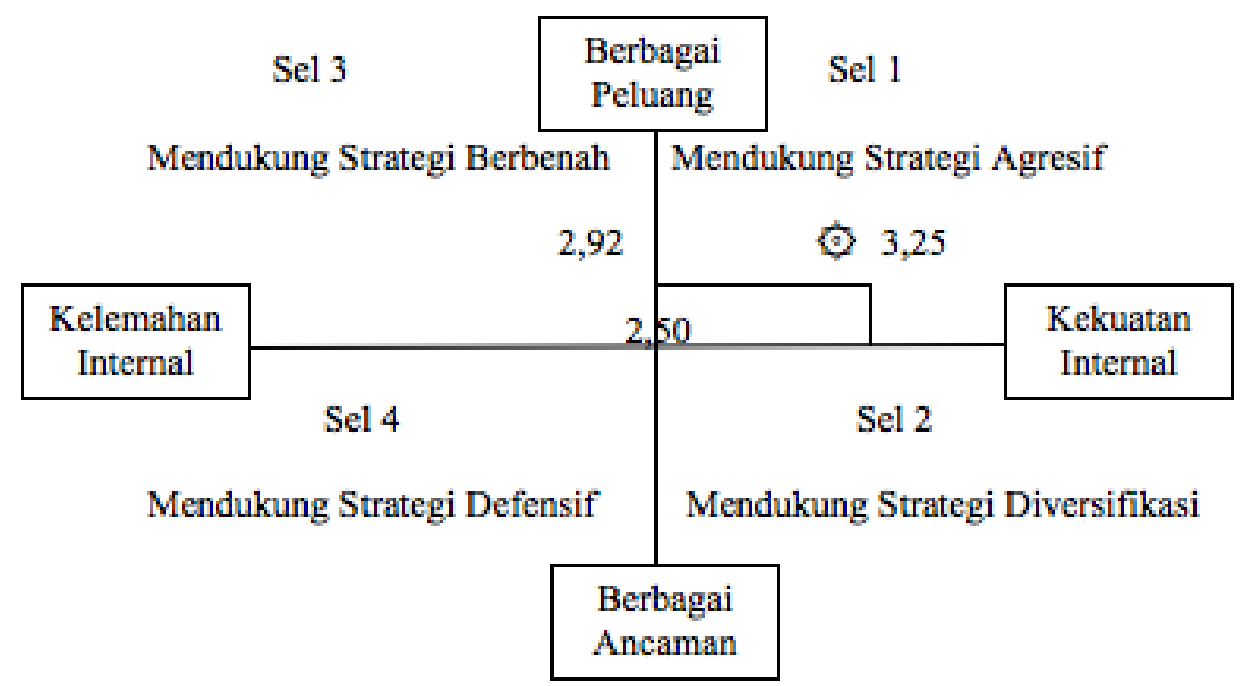

Gambar 4. Diagram Analisis SwoT

Keterangan : $\&$ Posisi Bank Sampah Garuda Wastu Lestari

Tabel 2. Identifikasi Faktor-Faktor Kekuatan dan Kelemahan

\begin{tabular}{|c|c|c|}
\hline Bidang Fungsional & Kekuatan & Kelemahan \\
\hline Manajemen & $\begin{array}{l}\text { - Hubungan baik antara } \\
\text { pekerja dan pemilik } \\
\text { usaha } \\
\text { Manajemen berjalan } \\
\text { secara kekeluargaan dan } \\
\text { tidak kaku }\end{array}$ & $\begin{array}{l}\text { Keterbatasan pengelola } \\
\text { yang belum sepenuhnya } \\
\text { mampu menerima } \\
\text { pelimpahan wewenang }\end{array}$ \\
\hline $\begin{array}{l}\text { Pemasaran } \\
\text { Distribusi }\end{array}$ & $\begin{array}{l}\text { - Harga beli sampah } \\
\text { yang ditawarkan } \\
\text { bersaing dan stabil } \\
\text { - Hubungan yang baik } \\
\text { dengan nasabah dan } \\
\text { masyarakat }\end{array}$ & $\begin{array}{l}\text { - Tenaga promosi dan } \\
\text { sosialisasi yang masih } \\
\text { terbatas dan kurang } \\
\text { terlatih }\end{array}$ \\
\hline $\begin{array}{l}\text { Produksi dan Pelayanan } \\
\text { Jasa }\end{array}$ & $\begin{array}{l}\text { - Menerapkan } \\
\text { pengomposan yang } \\
\text { praktis } \\
\text { - Penyelenggaraan } \\
\text { pelayanan jasa dengan } \\
\text { waktu yang fleksibel }\end{array}$ & $\begin{array}{l}\text { - Kurang memiliki } \\
\text { variasi tabungan yang } \\
\text { ditawarkan } \\
\text { - Kurang memiliki } \\
\text { inovasi dan } \\
\text { pengembangan produk } \\
\text { daur ulang }\end{array}$ \\
\hline
\end{tabular}




\begin{tabular}{|c|c|c|}
\hline & & $\begin{array}{l}\text { - Terbatasnya gudang } \\
\text { yang dimiliki untuk } \\
\text { pemilahan dan } \\
\text { penyimpanan sampah }\end{array}$ \\
\hline $\begin{array}{l}\text { Keuangan dan } \\
\text { Akuntansi }\end{array}$ & $\begin{array}{l}\text { - Telah memiliki sistem } \\
\text { keuangan dan } \\
\text { akuntansi sesuai } \\
\text { standar akuntansi }\end{array}$ & $\begin{array}{l}\text { - Sistem akuntansi yang } \\
\text { dijalankan masih } \\
\text { sederhana } \\
\text { - Kurangnya } \\
\text { ketersediaan modal } \\
\text { usaha } \\
\text { - Tenaga administrasi } \\
\text { yang terbatas } \\
\text { menyebabkan } \\
\text { tercecernya beberapa } \\
\text { transaksi }\end{array}$ \\
\hline $\begin{array}{l}\text { Penelitian dan } \\
\text { Pengembangan }\end{array}$ & $\begin{array}{l}\text { - Adanya usaha dalam } \\
\text { menginvestasikan } \\
\text { sumber daya dalam } \\
\text { pengembangan sistem } \\
\text { penyelenggaraan } \\
\text { usahanya }\end{array}$ & - \\
\hline Sumber Daya Manusia & $\begin{array}{l}\text { - Memiliki tenaga kerja } \\
\text { yang loyal terhadap } \\
\text { perusahaan } \\
\text { - Ketersediaan SDM di } \\
\text { sekitar unit usaha }\end{array}$ & $\begin{array}{l}\text { - Terbatasnya jumlah } \\
\text { tenaga kerja yang } \\
\text { dimiliki } \\
\text { - Keterampilan SDM } \\
\text { dalam semua divisi } \\
\text { yang masih perlu untuk } \\
\text { terus dibina dan dilatih }\end{array}$ \\
\hline Sistem Informasi & & $\begin{array}{l}\text { - Belum menyediakan } \\
\text { Sistem Informasi } \\
\text { Manajemen (SIM) }\end{array}$ \\
\hline
\end{tabular}

Tabel 3. Identifikasi Faktor-Faktor Peluang dan Ancaman

\begin{tabular}{|l|l|l|}
\hline Bidang Fungsional & Peluang & Ancaman \\
\hline Kondisi & - Banyaknya kredit & - Meningkatnya harga \\
Perekonomian & bagi usaha kecil & BBM akan \\
& menengah & mempengaruhi \\
& - Adanya peluang CSR & beban operasional \\
& dan bantuan dari & perusahaan \\
& lembaga yang & \\
& memiliki komitmen & \\
& terhadap lingkungan & \\
\hline
\end{tabular}




\begin{tabular}{|c|c|c|}
\hline & $\begin{array}{l}\text { Meningkatnya } \\
\text { timbulan sampah } \\
\text { seiring meningkatnya } \\
\text { jumlah penduduk } \\
\text { urban dengan gaya } \\
\text { konsumerisme }\end{array}$ & \\
\hline Sosial Budaya & $\begin{array}{l}\text { - Peningkatan } \\
\text { kesadaran } \\
\text { masyarakat akan } \\
\text { pentingnya } \\
\text { pengelolaan sampah } \\
\text { mulai dari rumah } \\
\text { tangga } \\
\text { - Membantu } \\
\text { masyarakat } \\
\text { mengumpulkan } \\
\text { sampah yang sudah } \\
\text { mereka pilah }\end{array}$ & $\begin{array}{l}\text { - Dikhawatirkan } \\
\text { menurunnya niat } \\
\text { masyarakat untuk } \\
\text { mengurangi sampah } \\
\text { - }\end{array}$ \\
\hline Teknologi & $\begin{array}{l}\text { Dengan input yang } \\
\text { rutin berpeluang } \\
\text { mengembangkan } \\
\text { usaha dengan } \\
\text { teknologi tinggi dalam } \\
\text { pengelolaan sampah }\end{array}$ & \\
\hline $\begin{array}{l}\text { Politik dan Kebijakan } \\
\text { Pemerintah }\end{array}$ & $\begin{array}{l}\text { - Secara politik dan } \\
\text { kebijakan } \\
\text { pemerintah sangat } \\
\text { mendukung } \\
\text { keberadaan bank } \\
\text { sampah }\end{array}$ & $\begin{array}{l}\text { Bisa dijadikan ajang } \\
\text { politik sebagai } \\
\text { komoditas dalam } \\
\text { pertarungan bagi } \\
\text { calon-calon pejabat }\end{array}$ \\
\hline $\begin{array}{l}\text { Masuknya Pendatang } \\
\text { Baru }\end{array}$ & $\begin{array}{l}\text { Pendatang baru dalam } \\
\text { pengelolaan sampah } \\
\text { merupakan mitra } \\
\text { seperjuangan untuk } \\
\text { melayani masyarakat }\end{array}$ & \\
\hline $\begin{array}{l}\text { Kekuatan Tawar } \\
\text { Menawar Nasabah }\end{array}$ & $\begin{array}{l}\text { Nasabah mengikuti } \\
\text { aturan ketetapan harga } \\
\text { yang dikeluarkan bank } \\
\text { sampah }\end{array}$ & $\begin{array}{l}\text { Harga penawaran } \\
\text { yang rendah membuat } \\
\text { masyarakat malas } \\
\text { menabung sampah }\end{array}$ \\
\hline $\begin{array}{l}\text { Kekuatan Tawar } \\
\text { Menawar Lapak } \\
\text { (Pengepul Besar) }\end{array}$ & $\begin{array}{l}\text { Bank sampah dan } \\
\text { pelapak memiliki } \\
\text { kekuatan tawar } \\
\text { menawar yang sama }\end{array}$ & $\begin{array}{l}\text { Tergiur penawaran } \\
\text { harga tinggi sesaat } \\
\text { dari pihak lain dapat } \\
\text { merusak hubungan } \\
\text { kemitraan dengan }\end{array}$ \\
\hline
\end{tabular}




\begin{tabular}{|c|c|c|}
\hline & $\begin{array}{l}\text { karena memiliki } \\
\text { kesepakatan kerjasama }\end{array}$ & $\begin{array}{l}\text { lapak yang telah } \\
\text { terjalin }\end{array}$ \\
\hline $\begin{array}{l}\text { Persaingan dengan } \\
\text { Bank Sampah } \\
\text { Lainnya }\end{array}$ & $\begin{array}{l}\text { - Bank sampah } \\
\text { tergabung dalam } \\
\text { paguyuban untuk } \\
\text { menguatkan jaringan } \\
\text { bank sampah } \\
\text { Jaringan bank sampah } \\
\text { menjadi ruang } \\
\text { koordinasi dalam } \\
\text { menjaga stabilitas } \\
\text { harga dan pelayanan } \\
\text { kepada masyarakat }\end{array}$ & $\begin{array}{l}\text { - Bank sampah di luar } \\
\text { paguyuban memiliki } \\
\text { wilayah kerja dan } \\
\text { jaringan distribusi } \\
\text { yang lebih luas }\end{array}$ \\
\hline $\begin{array}{l}\text { Persaingan dengan } \\
\text { Para Pemulung }\end{array}$ & $\begin{array}{l}\text { - Meningkatnya } \\
\text { kesadaran } \\
\text { masyarakat } \\
\text { banjar/lingkungan } \\
\text { menolak keberadaan } \\
\text { pemulung }\end{array}$ & $\begin{array}{l}\text { Pemulung } \\
\text { menghalalkan } \\
\text { berbagai cara untuk } \\
\text { merebut nasabah yang } \\
\text { dapat merusak harga }\end{array}$ \\
\hline
\end{tabular}


Jurnal Satyagraha, Vol. 01, No. 02, Agustus 2018 - Januari 2019 ISSN : 2620-6358

\section{Penyusunan Matriks SWOT}

Berdasarkan analisis lingkungan internal dan ekternal perusahaan maka dapat diformulasikan alternatif strategi yang dapat dilaksanakan. Formulasi strategi ini dilakukan dengan analisis SWOT. Analisis SWOT merupakan salah satu cara bagi pihak perusahaan untuk mengetahui kondisi suatu perusahaan, baik kondisi yang berada langsung dalam perusahaan dan kondisi di luar perusahaan yang mampu mempengaruhi kondisi perusahaaan. Setelah melakukan analisis SWOT di atas maka dapat dibuat beberapa alternatif strategi melalui penyusunan kekuatan, kelemahan, peluang, dan ancaman yang dimiliki perusahaan ke dalam matriks SWOT.

\section{Penentuan Alternatif Strategi}

Berdasarkan hasil analisis matriks SWOT, maka alternatif yang dapat diperoleh adalah sebagai berikut:

\section{Strategi $S-O$}

a. Mempertahankan dan meningkatkan kualitas pelayanan yang dihasilkan.

Untuk dapat mempertahankan dan meningkatkan kualitas pelayanan Bank Sampah Garuda Wastu Lestari dapat memanfaatkan kekuatan yang dimiliki perusahaan sebagai contoh adanya hubungan baik antara pekerja dengan pemilik usaha serta manajemen yang berjalan secara kekeluargaan dan tidak kaku. Dengan adanya hal tersebut akan menciptakan suasana kerja yang baik, sehingga baik pekerja maupun pemilik bisa saling mendukung dan saling mengingatkan untuk bisa mempertahankan kualitas pelayanan yang dihasilkan. Selain itu, para pekerja tidak akan enggan untuk menyampaikan ide-ide yang dapat membantu meningkat kualitas produk.

b. Mempertahankan dan meningkatkan hubungan baik dengan pekerja, nasabah, dan lembaga atau instansi terkait.

Bank Sampah Garuda Wastu Lestari yang memiliki keingainan untuk terus mengembangkan usahanya harus dapat menjaga hubungan yang baik dengan pekerja, nasabah, maupun lembaga atau dinas terkait yang selama ini telah diajak kerjasama. Selama ini Bank Sampah Garuda Wastu Lestari telah menajalin kerjasama yang baik dengan Yayasan Unilever Indonesia dan Pemerintah Kota Denpasar. Hubungan yang baik dengan pekerja akan memudahkan pemilik dalam mengatur manajemen perusahaan.

Hubungan yang baik dengan nasabah akan menjaga dan meningkatkan penerimaan sampah sehingga dapat meningkatkan pendapatan perusahaan. Hubungan yang baik dengan lembaga/instansi terkait akan memudahkan perusahaan dalam mendapatkan bantuan sarana dan prasarana serta pembinaan dan pelatihan dari lembaga/instansi tersebut dalam pengembangan usaha bank sampah.

c. Mempertahankan dan meningkatkan kegiatan promosi dan sosialisasi.

Bank sampah merupakan sebuah unit bisnis yang baru dan belum begitu dikenal luas oleh masyarakat. Dalam usaha memperkenalkan usaha ini kepada masyarakat dari seluruh lapisan perlu dilakukan peningkatan kegiatan promosi dan sosialisasi. Promosi yang telah dilakukan melalui penyebaran pamflet yang telah dilakukan sejak awal perlu dipertahankan dan terus ditingkatkan 
Jurnal Satyagraha, Vol. 01, No. 02, Agustus 2018 - Januari 2019 ISSN : 2620-6358

terutama di daerah yang jauh dari bank sampah. Sosialisasi ke sekolah-sekolah serta banjar-banjar harus dilanjutkan dengan menyasar sekolah-sekolah dan banjar-banjar yang belum pernah dikunjungi. Selain itu, pemanfaatan teknologi di bidang informasi dan komunikasi perpeluang untuk dimanfaatkan secara maksimal, dari pembuatan facebook, pembuatan blog, hingga pembuatan website.

d. Meningkatkan kerjasama dan jaringan bank sampah.

Jaringan bank sampah yang sudah terbentuk yaitu Sekaa Bank Sampah Kota Denpasar yang berada di bawah binaan dan pendampingan dari Lembaga Bali Wastu Lestari berperan besar dalam menjaga persaingan dan menjaga stabilitas pelayanan kepada masyarakat. Terlebih dengan adanya pemberlakuan harga sampah yang sama pada masing-masing bank sampah binaan akan menghindari persaingan yang tidak sehat misalnya dengan merusak harga dengan penawaran harga yang sembarangan.

\section{Strategi $\mathrm{W}-\mathrm{O}$}

a. Memanfaatkan skim kredit dan bantuan dari berbagai lembaga untuk meningkatkan kapasitas usaha.

Keterbatasan modal yang dimiliki oleh Bank Sampah Garuda Wastu Lestari sangat berpengaruh terhadap perkembangan usaha yang dijalankan. Bank Sampah Garuda Wastu Lestari belum mampu memberikan pelayanan secara optimal karena masih terbatasnya sarana dan prasarana yang dimiliki. Bank sampah ini sangat membutuhkan gudang sebagai tempat penyimpanan sampah yang disetorkan oleh para nasabah. Terbatasnya tempat penyimpanan yang ada saat ini membuat bank sampah ini belum bisa bekerjasama langsung dengan pabrik daur ulang, dan harus melakukan kerjasama dengan pelapak. Ini tentu berpengaruh terhadap harga jual beli sampah yang berhasil dihimpun. Untuk mengatasi permasalahan ini Bank Sampah Garuda Wastu Lestari dapat memanfaatkan skim kredit atau mengajukan proposal bantuan kepada instansi/lembaga terkait. Namun untuk mengajukan bantuan tersebut disyaratkan pencatatan keuangan yang sudah tertata dengan baik sesuai standar akuntansi keuangan. Oleh karena itu, Bank Sampah Garuda Wastu Lestari harus meningkatkan pencatatan keungannya sesuai standar akuntansi.

b. Inovasi pengembangan produk barang kerajinan daur ulang.

Bank Sampah Garuda Wastu Lestari telah melakukan penelitian tentang proses produksi produk barang kerajinan daur ulang dari sampah yang disetorkan para nasabah. Beberapa jenis barang kerajinan yang ingin dikembangkannya antara lain : tas, celengan, tempat pensil, vas bunga, bunag hias, tempat tisu serta berbagai souvenir sebagai cinderamata yang menarik. Saat ini masih dalam usaha survey dan penjajakan kepada tukang jahit dan tenaga kerja untuk melakukan 
Jurnal Satyagraha, Vol. 01, No. 02, Agustus 2018 - Januari 2019 ISSN : 2620-6358

kerjasama dalam memproduksi produk yang dimaksud. Oleh karenanya saat ini barang daur ulang belum dipasarkan. Produksi masih dalam jumlah terbatas hanya diperuntukan untuk mengikuti pameran serta sebagai kenangkenangan yang diberikan kepada para tamu yang berkunjung ke bank sampah ini. Ke depan sebaiknya Bank Sampah Garuda Wastu Lestari segera melengkapi sumber daya yang dibutuhkan dalam proses produksi barang kerajian daur ulang sehingga produk bisa diproduksi dalam jumlah besar dan dipasarkan kepada masyarakat.

\section{Strategi $S-T$}

a. Mempertahankan tingkat penawaran harga bersaing dan pelayanan kepada nasabah.

Dengan adanya rancangan strategi baru dalam usaha memberikan pelayanan kepada nasabah yang mungkin untuk diaplikasikan oleh perusahaan tentunya akan meningkatkan biaya operasional. Bank Sampah Garuda Wastu Lestari harus cermat di dalam memperkirakan biaya operasional dan tanggap membaca fluktuasi harga jual sampah di pasaran. Bank sampah harus dapat memanfaatkan kekuatan yang ada untuk mengurangi ancaman yang mungkin terjadi. Kekuatan perusahaan seperti hubungan yang baik dengan nasabah dan masyarakat serta jaringan bank sampah akan membantu mengurangi ancaman yang menurunnya minat masyarakat untuk menabung sampah. Selain itu, pelayanan kepada nasabah harus dipertahankan atau bahkan ditingkatkan untuk menjaga kepuasan nasabah terhadap kinerja bank sampah.

b. Menambah variasi jenis tabungan yang ditawarkan kepada para nasabah.

Dalam penyelenggaraan usahanya, Bank Sampah Garuda Wastu Lestari hingga kini baru membuka satu jenis layanan tabungan, yaitu berupa tabungan reguler. Keberadan bank sampah akan semakin mendapat perhatian masyarakat karena adanya peluang meningkatnya timbulan sampah seiring meningkatnya jumlah penduduk serta penigkatan kesadaran masyarakat akan pentingnya pengelolaan sampah mulai dari rumah tangga. Pertambahan jumlah bank sampah juga semakin banyak seiring ditutupnya akses bagi pemulung, baik oleh pemeritah maupun oleh masyarakat sendiri. Untuk menangkap peluang ini Bank Sampah Garuda Wastu Lestari sebaiknya melakukan terobosan dengan menambah variasi jenis tabungan yang ditawarkan kepada para nasabah, sehingga masyarakat semakin tertarik untuk menjadi nasabahnya.

c. Terus melakukan upaya inovasi untuk menghadapi pesaing dan pendatang baru.

Hadirnya pendatang baru dalam pengelolaan sampah di Kota Denpasar sesungguhnya tidak 
Jurnal Satyagraha, Vol. 01, No. 02, Agustus 2018 - Januari 2019 ISSN : 2620-6358

serta merta menjadi ancaman bagi keberadaan bank sampah. Beberapa bank sampah yang hadir belakangan merupakan mitra kerjasama bagi Bank Sampah Garuda Wastu Lestari dalam melayani masyararakat. Terlebih bank sampah yang baru dibentuk itu merupakan bank sampah yang berada di bawah binaan Lembaga Bali Wastu Lestari, maka kerjasama yang terjadi akan semakin erat karena sistem yang diterapkan sama-sama merupakan sistem bank sampah dari Yayasan Unilever Indonesia (YUI). Begitu juga dengan harga beli sampah yang dikeluarkan sesuai harga yang ditetapkan oleh Lembaga Bali Wastu Lestari. Meskipun begitu, persaingan usaha tentu tetap ada. Oleh karena itu inovasi sangat dibutuuhkan bagi sebuah bank sampah untuk memperoleh pertumbuhan usaha.

\section{Strategi $W-T$}

a. Meningkatkan kualitas SDM melalui pembinaan dan pelatihan secara berkelanjutan

Kualitas sumber daya manusia (SDM) di dalam suatu perusahaan sangat mempengaruhi perkembangan perusahaan tersebut. Untuk meningkatkan kualitas SDM yang ada saat ini, Bank Sampah Garuda Wastu Lestari bisa memberikan pelatihan-pelatihan kepada pekerjanya dari semua divisi sesuai dengan tugas dan tanggung jawab yang diemban masingmasing. Kegiatan pelatihan tersebut meliputi pelatihan manajemen bank sampah sekaligus pelatihan pemilahan, kerajinan dan kompos. Sedangkan untuk menutupi kelemahan yang dimiliki, Bank Sampah Garuda Wastu Lestari bisa melakukan perekrutan pekerja baru sesuai dengan kualifikasi pekerjaan yang dibutuhkan saat ini. Selain itu, bank sampah perlu mengirimkan pekerjanya untuk mengikuti pembinaan dan pelatihan keterampilan mengenai bank sampah yang diselengarakan oleh berbagai instansi atau lembaga lain.

b. Memperbaiki pengelolaan keuangan dengan memanfaatkan komputerisasi

Menghadapi kelemahan perusahaan khususnya permasalahan kurangnya modal usaha, Bank Sampah Garuda Wastu Lestari harus bisa mengatur keuangan perusahaan sebaik mungkin. Bank Sampah Garuda Wastu Lestari dapat melakukannya dengan cara mengalokasikan modal yang ada secara tepat sehingga setiap unit kerja di bank sampah ini berjalan secara efektif dan efisien. Demikian juga diharapkan Bank Sampah Garuda Wastu Lestari dapat terus menjaga dan mempertahankan usahanya.

Dalam pengelolaan keuangannya bank sampah ini harus mulai beralih kepada pengelolaan dengan manajemen komputerisasi. Pembuatan jurnal harian harus dilakukan secara 
Jurnal Satyagraha, Vol. 01, No. 02, Agustus 2018 - Januari 2019 ISSN : 2620-6358

tertib, teratur, dan rapi. Pencatatan transaksi dan pembuatan laporan yang sesuai standar akuntansi perlahan dialihkan dengan komputerisasi. Perhatian yang serius perlu diberikan oleh perusahaan terhadap manajemen pengelolaan keuangannya sehingga tercecernya transaksi dapat dihindari.

\section{KESIMPULAN DAN SARAN Kesimpulan}

1. Berdasarkan identifikasi faktor-faktor internal Bank Sampah Garuda Wastu Lestari, perusahaan memiliki kekuatan dan kelemahan. Adapun kekuatan dan kelemahan internal yang berpengaruh terhadap pengembangan usaha Bank Sampah garuda Wastu Lestari adalah sebagai berikut:

a. Kekuatan perusahaan antara lain: hubungan baik antara pekerja dan pemilik usaha, manajemen berjalan secara kekeluargaan dan tidak kaku, harga beli sampah yang ditawarkan bersaing dan stabil, hubungan yang baik dengan nasabah dan masyarakat, menerapkan pengomposan yang praktis, penyelenggaraan pelayanan jasa dengan waktu yang fleksibel, telah memiliki sistem keuangan dan akuntansi sesuai standar akuntansi, adanya usaha menginvestasikan sumber daya dalam pengembangan sistem penyelenggaraan usahanya, memiliki tenaga kerja yang loyal terhadap perusahaan, dan ketersediaan SDM di sekitar unit usaha.

b. Kelemahan perusahaan antara lain : keterbatasan pengelola yang belum sepenuhnya mampu menerima pelimpahan wewenang, tenaga promosi dan sosialisasi yang masih terbatas dan kurang terlatih, kurang memiliki variasi tabungan yang ditawarkan, kurang memiliki inovasi dan pengembangan produk daur ulang, terbatasnya gudang yang dimiliki untuk pemilahan dan penyimpanan sampah, sistem akuntansi yang dijalankan masih sederhana, kurangnya ketersediaan modal usaha, tenaga administrasi yang terbatas menyebabkan tercecernya beberapa transaksi, terbatasnya jumlah tenaga kerja yang dimiliki, tingkat pendidikan SDM yang masih rendah, keterampilan SDM dalam semua divisi yang masih perlu untuk terus dibina dan dilatih, dan belum menyediakan Sistem Informasi Manajemen (SIM) perusahaan.

2. Berdasarkan identifikasi faktor-faktor eksternal Bank Sampah Garuda Wastu Lestari yaitu lingkungan jauh dan lingkungan industri, dalam pengembangan usahanya perusahaan menghadapi berbagai peluang dan ancaman sebagai berikut:

a. Peluang perusahaan antara lain: banyaknya kredit bagi usaha kecil menengah, adanya peluang $C S R$ dan bantuan dari lembaga yang memiliki komitmen terhadap lingkungan, meningkatnya timbulan sampah seiring meningkatnya jumlah penduduk urban dengan gaya konsumerisme, peningkatan kesadaran masyarakat akan pentingnya pengelolaan sampah mulai dari rumah tangga, membantu masyarakat mengumpulkan sampah yang sudah mereka pilah, dengan input 
Jurnal Satyagraha, Vol. 01, No. 02, Agustus 2018 - Januari 2019 ISSN : 2620-6358

yang rutin berpeluang mengembangkan usaha dengan teknologi tinggi dalam pengelolaan sampah, secara politik dan kebijakan pemerintah sangat mendukung keberadaan bank sampah, pendatang baru dalam pengelolaan sampah merupakan mitra seperjuangan untuk melayani masyarakat, nasabah mengikuti aturan ketetapan harga yang dikeluarkan bank sampah, bank sampah dan pelapak memiliki kekuatan tawar menawar yang sama karena memiliki kesepakatan kerjasama, bank sampah tergabung dalam paguyuban untuk menguatkan jaringan bank sampah, jaringan bank sampah menjadi ruang koordinasi dalam menjaga stabilitas harga dan pelayanan kepada masyarakat, dan meningkatnya kesadaran masyarakat banjar/lingkungan menolak keberadaan pemulung.

b. Ancaman yang dihadapi perusahaan antara lain: meningkatnya harga BBM akan mempengaruhi beban operasional perusahaan, dikhawatirkan menurunnya niat masyarakat untuk mengurangi sampah, bisa dijadikan ajang politik sebagai komoditas dalam pertarungan bagi calon-calon pejabat, harga penawaran yang rendah membuat masyarakat malas menabung sampah, tergiur penawaran harga tinggi sesaat dari pihak lain dapat merusak hubungan kemitraan dengan lapak yang telah terjalin, bank sampah di luar paguyuban memiliki wilayah kerja dan jaringan distribusi yang lebih luas, dan pemulung menghalalkan berbagai cara untuk merebut nasabah yang dapat merusak harga.
3. Berdasarkan penyusunan Matriks SWOT dihasilkan sebelas strategi yang mungkin diupayakan dalam usaha pengembangan Bank Sampah Bali Wastu Lestari. Alternatif tersebut dirinci sebagai berikut:

a. Strategi S-O: mempertahankan dan meningkatkan kualitas pelayanan yang dihasilkan, mempertahankan dan meningkatkan hubungan baik dengan pekerja, nasabah, dan lembaga atau instansi terkait, mempertahankan dan meningkatkan kegiatan promosi dan sosialisasi, serta meningkatkan kerjasama dan jaringan bank sampah.

b. Strategi $W-O$ : memanfaatkan skim kredit dan bantuan dari berbagai lembaga untuk meningkatkan kapasitas usaha, serta inovasi pengembangan produk barang kerajinan daur ulang.

c. Strategi $S-T$ : mempertahankan tingkat penawaran harga bersaing dan pelayanan kepada nasabah, menambah variasi jenis tabungan yang ditawarkan kepada para nasabah, terus melakukan upaya inovasi untuk menghadapi pesaing dan pendatang baru.

d. Strategi $W-T$ : meningkatkan kualitas SDM melalui pembinaan dan pelatihan secara berkelanjutan serta memperbaiki pengelolaan keuangan dengan memanfaatkan komputerisasi.

4. Sesuai Diagram Analisis SWOT hasil penilaian para responden menunjukan posisi Bank Sampah Garuda Wastu Lestari adalah posisi dengan variabel internal 3,25 dan variabel eksternal 2,92; terlihat perusahaan berada pada Sel 1. Ini merupakan situasi yang sangat 
Jurnal Satyagraha, Vol. 01, No. 02, Agustus 2018 - Januari 2019 ISSN : 2620-6358

menguntungkan perusahaan tersebut memiliki peluang dan kekuatan sehingga dapat memanfaatkan peluang yang ada. Strategi yang harus diterapkan dalam kondisi ini adalah mendukung kebijakan pertumbuhan yang agresif. Dengan demikian prioritas strategi yang tepat untuk diterapkan pada Bank Sampah Garuda Wastu Lestari sesuai dengan kondisi lingkungan usahanya saat ini adalah dengan Strategi $S$-O (StrenghtOpportunity), memanfaatkan kekuatan yang dimiliki perusahaan untuk merebut peluang yang ada.

\section{Saran}

1. Usaha yang dijalankan Bank Sampah Garuda Wastu Lestari selama ini memiliki beberapa kelemahan, terutama modal usaha yang terbatas. Hingga saat ini Bank Sampah Garuda Wastu Lestari belum memiliki gudang yang memadai yang mampu menampung semua barang yang diserap dalam skala besar. Diharapkan Bank Sampah Garuda Wastu Lestari segera bisa memiliki gudang besar baik dibangun dengan modal pinjaman dari lembaga keuangan ataupun bantuan dari lembaga/instansi terkait. Dengan memiliki gudang yang mampu menyimpan sampah dalam volume besar maka Bank Sampah Garuda Wastu Lestari bisa melakukan kerjasama langsung dengan pihak pabrik daur ulang sehingga harga jual sampahnya bisa lebih tinggi. Dengan perolehan laba yang meningkat Bank Sampah Garuda Wastu Lestari akan mampu menjalankan perencanaan bisnisnya.

2. Pengembangan usaha bank sampah selain memerlukan usaha keras untuk mempertahankan kualitas pelayanan dan melakukan promosi dan sosialisasi, juga membutuhkan berbagai inovasi. Secara bertahap Bank Sampah Garuda Wastu Lestari dapat melakukan penambahan jenis tabungan, memproduksi barang kerajinan daur ulang, hingga merambah ke unit simpan pinjam. Pengembangan usaha yang juga penting dilakukan yaitu memanfaatkan penggunaan mesin pencacah plastik untuk mengolah sampah plastik menjadi bijih plastik. Penjualan plastik dalam bentuk bijih dapat bernilai 3 kali lebih tinggi dibandingkan dalam bentuk asli. Dengan pengembangan usaha ini akan menambah perolehan laba sehingga perencanaan bisnis mampu dilaksanakan.

\section{DAFTAR PUSTAKA}

Antara News. 1 Maret 2013. Indonesia miliki 1.195 Bank Sampah

http://www.antaranews.com/berita/3

61007/indonesia-miliki-1195-banksampah, diakses 20 Juni 2018.

David, F.R. 2006. Manajemen Strategi Edisi 10 Terjemahan. Jakarta: PT. Indeks Kelompok Gramedia.

2011. Manajemen Strategis Edisi 12

Terjemahan. Jakarta: Salemba Empat.

Faizah. 2008. Pengelolaan Sampah Rumah Tangga Berbasis Masyarakat. Tesis. Program Pasca Sarjana Universitas Diponegoro Semarang.

Nazir, Moh. 2005. Metode Penelitian. Jakarta: Ghalia Indonesia. 
Jurnal Satyagraha, Vol. 01, No. 02, Agustus 2018 - Januari 2019 ISSN : 2620-6358

Peraturan Menteri Negara Lingkungan Hidup Republik Indonesia Nomor 13 Tahun 2012 Tentang Pedoman Pelaksanaan Reduce, Reuse, dan Recycle Melalui Bank Sampah.

Pearce, John A. dan Richard B. Robinson. 2008. Manajemen Strategis: Formulasi, Implementasi, dan Pengendalian. Terjemahan. Jakarta: Salemba Empat.

Porter, M. 1997. Strategi Bersaing Teknik Menganalisis Industri dan Pesaing. Jakarta: Erlangga.

Undang-Undang Republik Indonesia No. 18 tahun 2008 Tentang Pengelolaan Sampah. 